\title{
The importance of the Wnt/ $\beta$-catenin pathway and LRP5 protein in bone metabolism of postmenopausal women
}

\author{
Adam Kamiński, ${ }^{1, A, B, F}$, Monika Karasiewicz 2,B-E, Anna Bogacz ${ }^{3,4, B-E}$, Karolina Dziekann ${ }^{3, B, C}$,

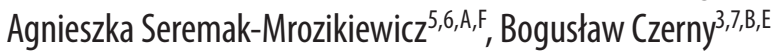 \\ 1 Department of Orthopedics and Traumatology, Independent Public Clinical Hospital No. 1, Pomeranian Medical University in Szczecin, Poland \\ ${ }^{2}$ Laboratory of International Health, Department of Preventive Medicine, Poznan University of Medical Sciences, Poland \\ ${ }^{3}$ Department of Stem Cells and Regenerative Medicine, Institute of Natural Fibres and Medicinal Plants, Plewiska, Poland \\ ${ }^{4}$ Department of Histocompatibility with Laboratory of Genetic Diagnostics, Regional Blood Center, Poznań, Poland \\ ${ }^{5}$ Division of Perinatology and Women's Diseases, Poznan University of Medical Sciences, Poland \\ ${ }^{6}$ Department of Pharmacology and Phytochemistry, Institute of Natural Fibres and Medicinal Plants, Plewiska, Poland \\ ${ }^{7}$ Department of General Pharmacology and Pharmacoeconomics, Pomeranian Medical University in Szczecin, Poland \\ A - research concept and design; B - collection and/or assembly of data; $C$ - data analysis and interpretation; \\ $D$ - writing the article; $E$ - critical revision of the article; $F$ - final approval of the article
}

Address for correspondence

Monika Karasiewicz

E-mail: karasiewicz.m@wp.pl

Funding sources

None declared

Conflict of interest

None declared

Received on January 16, 2017

Reviewed on February 12, 2017

Accepted on November 8, 2017

Published online on July 2, 2018

Cite as

Kamiński A, Karasiewicz M, Bogacz A, Dziekan K, Seremak-Mrozikiewicz A, Czerny B. The importance of the Wnt/ $/$-catenin pathway and LRP5 protein in bone metabolism of postmenopausal women. Adv Clin Exp Med. 2019;28(2):179-184. doi:10.17219/acem/79969

DOI

10.17219/acem/79969

Copyright

Copyright by Author(s)

This is an article distributed under the terms of the

Creative Commons Attribution Non-Commercial License

(http://creativecommons.org/licenses/by-nc-nd/4.0/)

\section{Abstract}

Background. Postmenopausal osteoporosis is the most common metabolic bone disease among women. The Wnt signaling pathway has been known to be the critical regulator of osteoblastogenesis. Alterations in this mechanism may have consequences for bone remodeling in humans.

Objectives. The aim of the study was to evaluate the frequency of genotypes and alleles of single nucleotide polymorphism (SNP) rs4988321 and rs312009 of LRP5 in Polish postmenopausal women with osteopenia $(n=109)$ and osteoporosis $(n=333)$. Potential correlations between genetic polymorphisms, bone mineral density (BMD), risk for bone fractures, and other clinical parameters were analyzed.

Material and methods. Genomic DNA was extracted from the blood samples and the sequence polymorphisms of $\angle R P 5$ gene were detected using real-time polymerase chain reaction (RT-PCR) methods with melting curve analysis. We also calculated the odds ratio (OR) for the LRP5 genotypes and the alleles. Then, we evaluated the effect of the LRP5 polymorphism on T-score, Z-score, L2L4AM, L2L4YA, L2L4BMD, body mass index (BMI), and other clinical parameters.

Results. No statistically significant differences in the distribution of LRP5 rs312009 genotypes between the groups were observed. Furthermore, our findings indicate that there is no correlation between LRP5 genotypes and the clinical characteristics of women with osteopenia/osteoporosis. In contrast, there was an increased value of $O R$ in heterozygotes for rs 4988321, both in patients with osteopenia $(O R=1.47)$ and in those with osteoporosis $(O R=1.33)$. In our study, we were not able to calculate the OR parameter for the AA genotype due to its low prevalence in the population.

Conclusions. Our results suggest that the Val667Met LRP5 (rs312009) polymorphism may contribute to an elevated risk for fractures in postmenopausal Polish women.

Key words: bone mineral density, LRP5, postmenopausal women, osteoporosis 


\section{Introduction}

Osteoporosis is typically manifested by disturbances in the microstructure of bone tissue and increased susceptibility to bone fracture due to reduced bone mass. Due to its high incidence among patients over 50 years of age and the considerable costs of treatment, osteoporosis continues to be one of the greatest health challenges of an aging society. Osteoporotic fractures, which constitute the main consequences of the asymptomatic course of the disease, usually lead to long-term disability and even death. Over the last decade, studies on candidate genes, family analysis and genome-wide association studies (GWAS) resulted in the identification of numerous genetic loci related to osteoporosis. Genetic factors are believed to constitute $50-80 \%$ of individual differences in bone mineral density (BMD). ${ }^{1}$ Studies on the background of skeletal dysplasias with decreased bone mass, e.g., brittle bone disease and the osteoporosis-pseudoglioma syndrome, pointed to the role of the Wnt/ $\beta$-catenin pathway - including low-density lipoprotein receptor-related protein 5 (LRP5) and WNT1 - in the regulation of bone tissue homeostasis. ${ }^{2-4}$

The Wnt signaling pathway increases the activity and differentiation of bone marrow stem cells and stimulates the osteoblast lines, with a simultaneous decrease toward chondrogenic and adipogenic cell lines. Activation of that pathway inhibits the apoptosis of mature osteoblasts, thus extending their resilience. ${ }^{5}$ Additionally, the Wnt/ $\beta$-catenin pathway decreases osteoclast differentiation by stimulating the synthesis and secretion of osteoprotegerin, which regulates bone resorption by inhibiting osteoclast differentiation into mature forms. ${ }^{6}$ The canonical Wnt signaling pathway plays an essential role in the regulatory processes of bone formation, so its disturbed activity may result in grave consequences for bone metabolism. ${ }^{7-10}$ In short, LRP-5 and LRP-6 proteins, which belong to the low-density lipoprotein-receptor-related proteins (LDL) receptor family, function in this pathway as 1-domain coreceptors which, together with Fzd 7-domain endothelial receptor, facilitate the binding of the Wnt glycoproteins and the activation of cell response through $\beta$-catenin and Tcf/Lef factor-dependent transcription. The details of the Wnt signaling pathway have already been described. ${ }^{11,12}$ The Wnt/ $\beta$-catenin pathway is subject to antagonist regulation, sclerostin, Dkk1 and Dkk2, and Wnt modulator of surface ectoderm (Wise), for example, which - by binding to PRP5 - block access for the Wnt proteins and inhibit the classic signaling pathway, thus inhibiting osteoblastogenesis, induced via the $\mathrm{Wnt} / \beta$-catenin pathway. The LRP5 gene is expressed in the osteoblasts, and in vitro and in vivo studies have confirmed that its deletion inhibited osteoblast function, causing serious anomalies in bone phenotype. ${ }^{7-9}$ This protein, via the Wnt pathway, influences the bone mass. The connection between the sequence polymorphism of that gene and bone mineral density (BMD) has been extensively studied. ${ }^{13}$
The review of the latest literature reports revealed that single nucleotide polymorphism (SNP) changes in genes encoding the LRP family proteins may also affect bone phenotype and, at the same time, present a risk for osteoporosis. ${ }^{14}$ Studies on the phenotype-genotype relationship regarding osteoporosis seem to be crucial for early diagnosis and the development of treatment for postmenopausal osteoporosis, osteoarthritis, rheumatoid arthritis, and rare bone diseases.

\section{Objectives}

The aim of the study was to evaluate the frequency of the genotypes and alleles of SNP rs4988321 and rs312009 of LRP5 in Polish postmenopausal women with osteopenia $(\mathrm{n}=109)$ and osteoporosis $(\mathrm{n}=333)$. The potential correlations between genetic polymorphisms, BMD, risk for bone fractures, and other clinical parameters were analyzed.

\section{Material and methods}

\section{Patients}

The study included 109 unrelated postmenopausal Caucasian women with osteopenia (mean age: $53.24 \pm 8.12$ years) and 333 patients with osteoporosis (mean age: 56.06 \pm 8.83 years). The control group consisted of 233 postmenopausal women with normal T-scores (mean age: $53.38 \pm 8.2$ years) recruited from the patients of the same hospital. Blood samples were collected at the Department of Orthopedics and Traumatology, Pomeranian Medical University in Szczecin, Poland. Bone densitometry was performed at the Laboratory of Densitometry, Clinical Hospital No. 1, Pomeranian Medical University in Szczecin, Poland, to determine the BMD values, T-scores and $\mathrm{Z}$-scores. Bone mineral density was detected in the lumbar spine from L2 to L4 vertebrae using the dual energy X-ray absorptiometry (DEXA) method. Densitometry was performed using a Lunar DPX 100 camera (Lunar Corp., Madison, USA). A normal BMD value by DEXA is between one standard deviation (SD) from the mean with respect to the age of peak bone mass $(-1<\mathrm{T}$-score $>1)$. Based on these measurements, the women were classified into the following groups: osteopenia $(-2.5<\mathrm{T}$-score $\leq 1)$, osteoporosis (T-score $\leq 2.5)$ and normal T-score $(\mathrm{T}$-score $\geq 1)$. The ratio of the average BMD in relation to the mean value for young adults (YA) and in comparison to age (age-matched - AM) was also evaluated. Furthermore, height and weight were measured and the body mass index (BMI) was calculated. During an interview with each patient, data on disease manifestation, drug use, age at $1^{\text {st }}$ and last menstruation, gravidity, and birth weight were collected. The inclusion criteria for the genetic research were as follows: menopause at least 1 year before participation in the study, and no 
hormone replacement therapy (HRT) or drugs taken affecting bone mass (selective estrogen receptor modulators (SERMs), calcitonin, bisphosphonates, heparin, steroids, thyroid hormones, antiepileptic drugs, GnRH analogues, or tibolone). The study excluded patients with endocrine and metabolic disorders, hematological diseases, kidney disease, cancer, and autoimmune and connective tissue disease, as well as who had undergone bilateral ovariectomy. Written informed consent was obtained from each patient. The Pomeranian Medical University Ethics Committee approved the study (approval No. KB-0012/100/15).

\section{Genetic analysis}

Genetic polymorphisms were determined at the Department of Stem Cell and Regenerative Medicine at the Institute of Natural Fibers and Medicinal Plants in Poznań, Poland. Genomic DNA was obtained from $5 \mathrm{~mL}$ of whole blood using a Qiagen DNA isolation kit (Qiagen, Hilden, Germany), according to the manufacturer's protocol. DNA concentration was measured using a DeNovix DS-11 Spectrophotometer (DeNovix Inc., Wilmington, USA). A LightCycler FastStart DNA Master HybProbe (Roche Diagnostics, Risch-Rotkreuz, Switzerland) assay and a LightCycler ${ }^{\circledR} 480$ instrument for LRP5 gene genotyping were used. The LRP5 gene polymorphisms were performed using a LightSNiP LRP5 (TIBMolbiol, Berlin, Germany), which contained the primers and probes specific for the amplified fragment. Polymerase chain reaction (PCR) was performed in $10 \mu \mathrm{L}$ of reaction mixture, according to the manufacturer's protocol, under the following conditions: initial denaturation at $95^{\circ} \mathrm{C}$ for $10 \mathrm{~min}, 35$ cycles (denaturation at $95^{\circ} \mathrm{C}$ for $10 \mathrm{~s}$, annealing at $60^{\circ} \mathrm{C}$ for $10 \mathrm{~s}$, elongation for $15 \mathrm{~s}$ at $72^{\circ} \mathrm{C}$, and melting for $30 \mathrm{~s}$ at $95^{\circ} \mathrm{C}$ and $40^{\circ} \mathrm{C}$ for 120 s). Polymorphism LRP5 gene sequences were observed as different melting curves of PCR products. SPSS Statistics v. 17.0 for Windows (IBM Corp., Armonk, USA) was used for statistical analysis. We used the Hardy-Weinberg equation to calculate the expected genotype frequencies for each polymorphism, which were compared with the observed values using $X^{2}$ test. The expected results are presented with $95 \%$ confidence intervals (CI). We also calculated the odds ratio (OR) for the genotypes and the alleles. Then, we evaluated the effect of the LRP5 polymorphism on T-score, Z-score, L2L4AM, L2L4YA, L2L4BMD, BMI, and other clinical parameters. A correlation analysis between genotypes and clinical parameters using one-way analysis of variance (ANOVA) test was performed. A p-value $<0.05$ was considered statistically significant.

\section{Results}

The distribution of genotype frequency is consistent with the Hardy-Weinberg equation, both for LRP5 rs312009 (Tables 1-3) and rs4988321 (Table 3, 4). The $\chi^{2}$ test found no statistically significant differences between the values obtained for the rs312009 ( $\mathrm{p}=0.334$ ) and rs4988321

Table 1. Frequency of the genotype and allele of the LRP5 rs312009 polymorphism in women with osteopenia and the controls

\begin{tabular}{|c|c|c|c|c|c|c|c|}
\hline \multirow{2}{*}{$\begin{array}{l}\text { Genotype/ } \\
\text { allele }\end{array}$} & \multicolumn{2}{|c|}{ Osteopenia } & \multicolumn{2}{|c|}{ Controls } & \multirow[b]{2}{*}{ OR } & \multirow[b]{2}{*}{$95 \% \mathrm{Cl}$} & \multirow[b]{2}{*}{ p-value } \\
\hline & $\begin{array}{l}\text { observed value } \\
n[\%]\end{array}$ & $\begin{array}{c}\text { expected value } \\
{[\%]}\end{array}$ & $\begin{array}{l}\text { observed value } \\
\qquad n[\%]\end{array}$ & $\begin{array}{c}\text { expected value } \\
{[\%]}\end{array}$ & & & \\
\hline $\mathrm{CC}$ & 76 (69.7) & 68.9 & $141(60.5)$ & 61.6 & 1.50 & $0.90-2.53$ & 0.06 \\
\hline $\mathrm{CT}$ & 29 (26.6) & 28.2 & $84(36.1)$ & 33.8 & 0.64 & $0.37-1.09$ & 0.05 \\
\hline $\mathrm{TT}$ & $4(3.7)$ & 2.9 & $8(3.4)$ & 4.6 & 1.09 & $0.23-4.11$ & 0.57 \\
\hline Total & 109 (100) & 100 & $233(100)$ & 100 & - & - & - \\
\hline C & $181(83)$ & - & $366(78.5)$ & - & 1.34 & $0.87-2.09$ & 0.10 \\
\hline T & 37 (17) & - & $100(21.5)$ & - & 0.75 & $0.48-1.15$ & 0.10 \\
\hline Total & $218(100)$ & - & $466(100)$ & - & - & - & - \\
\hline
\end{tabular}

OR - odds ratio; $\mathrm{Cl}$ - confidence interval.

Table 2. Frequency of the genotype and allele of the LRP5 rs312009 polymorphism in women with osteoporosis and the controls

\begin{tabular}{|c|c|c|c|c|c|c|c|}
\hline \multirow{2}{*}{$\begin{array}{l}\text { Genotype/ } \\
\text { allele }\end{array}$} & \multicolumn{2}{|c|}{ Osteoporosis } & \multicolumn{2}{|c|}{ Controls } & \multirow[b]{2}{*}{ OR } & \multirow[b]{2}{*}{$95 \% \mathrm{Cl}$} & \multirow[b]{2}{*}{$p$-value } \\
\hline & $\begin{array}{c}\text { observed value } \\
n[\%]\end{array}$ & $\begin{array}{c}\text { expected value } \\
{[\%]}\end{array}$ & $\begin{array}{c}\text { observed value } \\
n[\%]\end{array}$ & $\begin{array}{c}\text { expected value } \\
{[\%]}\end{array}$ & & & \\
\hline$C C$ & $196(58.9)$ & 59.6 & $141(60.5)$ & 61.6 & 0.93 & $0.65-1.33$ & 0.38 \\
\hline $\mathrm{CT}$ & $122(36.6)$ & 35.2 & $84(36.1)$ & 33.8 & 1.02 & $0.71-1.48$ & 0.48 \\
\hline $\mathrm{TT}$ & $15(4.5)$ & 5.2 & $8(3.4)$ & 4.6 & 1.33 & $0.52-3.68$ & 0.34 \\
\hline Total & $333(100)$ & 100 & $233(100)$ & 100 & - & - & - \\
\hline C & $514(77.2)$ & - & 366 (78.5) & - & 0.92 & $0.69-1.24$ & 0.32 \\
\hline $\mathrm{T}$ & $152(22.8)$ & - & $100(21.5)$ & - & 1.08 & $0.81-1.46$ & 0.32 \\
\hline Total & $666(100)$ & - & $466(100)$ & - & - & - & - \\
\hline
\end{tabular}

OR - odds ratio; $\mathrm{Cl}$ - confidence interval. 
Table 3. Frequency of the genotype and allele of the LRP5 rs4988321 polymorphism in women with osteopenia and the controls

\begin{tabular}{|c|c|c|c|c|c|c|c|}
\hline \multirow{2}{*}{$\begin{array}{l}\text { Genotype/ } \\
\text { allele }\end{array}$} & \multicolumn{2}{|c|}{ Osteopenia } & \multicolumn{2}{|c|}{ Controls } & \multirow[b]{2}{*}{ OR } & \multirow[b]{2}{*}{$95 \% \mathrm{Cl}$} & \multirow[b]{2}{*}{$p$-value } \\
\hline & $\begin{array}{c}\text { observed value } \\
\mathrm{n}[\%]\end{array}$ & $\begin{array}{c}\text { expected value } \\
{[\%]}\end{array}$ & $\begin{array}{c}\text { observed value } \\
\mathrm{n}[\%]\end{array}$ & $\begin{array}{c}\text { expected value } \\
{[\%]}\end{array}$ & & & \\
\hline GG & 98 (89.9) & 89.3 & 1,218 (93.6) & 93.7 & 0.61 & $0.25-1.54$ & 0.17 \\
\hline GA & $10(9.2)$ & 10.4 & $15(6.4)$ & 6.2 & 1.47 & $0.57-3.63$ & 0.24 \\
\hline$A A$ & $1(0.9)$ & 0.3 & 0 & 0.1 & - & - & - \\
\hline Total & 109 (100) & 100 & $233(100)$ & 100 & - & - & - \\
\hline G & 206 (94.5) & - & 451 (96.8) & - & 0.57 & $0.24-1.36$ & 0.11 \\
\hline A & $12(5.5)$ & - & $15(3.2)$ & - & 1.75 & $0.73-4.09$ & 0.11 \\
\hline Total & $218(100)$ & - & $466(100)$ & - & - & - & - \\
\hline
\end{tabular}

OR - odds ratio; $\mathrm{Cl}$ - confidence interval.

Table 4. Frequency of the genotype and allele of the LRP5 rs4988321 polymorphism in women with osteoporosis and the controls

\begin{tabular}{|c|c|c|c|c|c|c|c|}
\hline \multirow{2}{*}{$\begin{array}{l}\text { Genotype/ } \\
\text { allele }\end{array}$} & \multicolumn{2}{|c|}{ Osteoporosis } & \multicolumn{2}{|c|}{ Controls } & \multirow[b]{2}{*}{ OR } & \multirow[b]{2}{*}{$95 \% \mathrm{Cl}$} & \multirow[b]{2}{*}{$p$-value } \\
\hline & $\begin{array}{c}\text { observed value } \\
n[\%]\end{array}$ & $\begin{array}{c}\text { expected value } \\
{[\%]}\end{array}$ & $\begin{array}{c}\text { observed value } \\
n[\%]\end{array}$ & $\begin{array}{c}\text { expected value } \\
{[\%]}\end{array}$ & & & \\
\hline GA & $28(8.4)$ & 8.0 & $15(6.4)$ & 6.2 & 1.33 & $0.67-2.75$ & 0.24 \\
\hline AA & 0 & 0.2 & 0 & 0.1 & - & - & - \\
\hline G & 638 (95.8) & - & 451 (96.8) & - & 0.76 & $0.37-1.49$ & 0.25 \\
\hline A & $28(4.2)$ & - & $15(3.2)$ & - & 1.32 & $0.67-2.69$ & 0.25 \\
\hline Total & $666(100)$ & - & $466(100)$ & - & - & - & - \\
\hline
\end{tabular}

OR - odds ratio; $\mathrm{Cl}$ - confidence interval.

$(\mathrm{p}=0.179)$ study groups. An analysis of genotype frequency for the LRP5 rs312009 polymorphism in women with osteopenia and osteoporosis and the controls revealed no statistically significant differences. No statistically significant differences were noted for allele frequency either (Tables 1, 2).

Increased OR values in heterozygotes for rs4988321 were noted in women with both osteopenia $(\mathrm{OR}=1.47$, $95 \% \mathrm{CI}=0.57-3.63, \mathrm{p}=0.24)$ and osteoporosis $(\mathrm{OR}=1.33$, $95 \% \mathrm{CI}=0.67-2.75, \mathrm{p}=0.24)$. In light of the sample size of our study, the OR for the AA genotype could not be established due to its relatively low incidence in the population. Increased $\mathrm{OR}$ values for the $\mathrm{A}$ allele were found in women with osteopenia $(\mathrm{OR}=1.75,95 \% \mathrm{CI}=0.73-4.09$, $\mathrm{p}=0.11)$ and osteoporosis $(\mathrm{OR}=1.32,95 \% \mathrm{CI}=0.67-2.69$, $\mathrm{p}=0.25$ ) (Tables 3,4$)$. The genotype analysis for both LRP5 polymorphisms revealed no statistically significant correlations in clinical features between the groups of women. Furthermore, characteristics of the study population (perimenopausal women with osteopenia, osteoporosis and normal T-scores) are presented in Table 5.

\section{Discussion}

The analyses of the genetic background of osteoporosis have indicated a relationship between a mutation in the 11q12-13 locus, the same one where the LRP5 gene is located, and the incidence of osteoporosis-pseudoglioma syndrome (OPPG), autosomal dominant phenotype of high bone mass (HBM) and autosomal dominant osteoporosis type I. ${ }^{15}$ Polymorphic variants, including Val667Met, have been suggested as being associated with BMD and the risk for fracture of various intensity and effect in different populations, which was confirmed by numerous multicenter studies. ${ }^{14}$ The aim of our study was to evaluate the frequency of the polymorphisms in the LRP5 gene in Polish postmenopausal women with osteopenia, osteoporosis, and normal T-scores, as well as to assess a possible relationship between genotypes and BMD values and other clinical features.

An analysis of genotype and allele frequency for the LRP5 rs312009 polymorphism in women with osteopenia and osteoporosis and healthy controls revealed no statistically significant differences. An earlier study by Agueda et al. postulated a link between BMD of the lumbar region of the spine and SNP LRP5 rs312009. ${ }^{16}$ A nucleotide change (SNP rs312009) was proved to be located in the LRP5 5' region at the RUNX2 binding site. The rs312009dependent variability was experimentally confirmed in 2 osteoblastic cell lines, with higher transcription activity in the $\mathrm{T}$ allele as compared to the $\mathrm{C}$ allele. In vitro studies found the mRNA LRP5 value to be RUNX2-dependent, thus proving a link between 2 bone-regulating systems - the RUNX2 transcription-factor cascade and the Wnt signaling pathway. ${ }^{17}$ Panach et al. found significantly lower L2-L4 BMD values in women with the CC genotype, and elevated risk for osteoporosis as compared to TT and $\mathrm{CT} .{ }^{18}$ 
Table 5. Characteristics of the study population (perimenopausal women with osteopenia, osteoporosis and normal T-scores)

\begin{tabular}{|c|c|c|c|c|c|c|}
\hline \multirow{2}{*}{\multicolumn{2}{|c|}{ Parameter }} & \multirow{3}{*}{$\begin{array}{l}\text { p-value } \\
<0.001^{b}\end{array}$} & \multirow{3}{*}{$\begin{array}{r}\text { Mean } \\
\\
-3.1640 \\
0.0779 \\
-1.8138\end{array}$} & \multirow{3}{*}{$\begin{array}{l}\text { SEM } \\
\\
\\
0.05627 \\
0.11321 \\
0.08072\end{array}$} & \multicolumn{2}{|c|}{$95 \% \mathrm{Cl}$} \\
\hline & & & & & \multirow{2}{*}{$\begin{array}{r}\text { lower limit } \\
-1.9072 \\
-3.2757 \\
-0.1482 \\
-1.9727\end{array}$} & \multirow{2}{*}{$\begin{array}{r}\text { upper limit } \\
-1.7530 \\
-3.0522 \\
0.3040 \\
-1.6549\end{array}$} \\
\hline T-score & $\begin{array}{c}\text { osteopenia } \\
\text { osteoporosis } \\
\text { controls } \\
\text { total }\end{array}$ & & & & & \\
\hline Z-score & $\begin{array}{l}\text { osteopenia } \\
\text { osteoporosis } \\
\text { controls } \\
\text { total }\end{array}$ & $\begin{array}{l}0.117^{\mathrm{a}} \\
<0.001^{\mathrm{b}}\end{array}$ & $\begin{array}{r}-0.8448 \\
-3.5691 \\
0.6425 \\
-1.6696\end{array}$ & $\begin{array}{l}0.08470 \\
1.94626 \\
0.19620 \\
0.81499\end{array}$ & $\begin{array}{r}-1.0143 \\
-7.4572 \\
0.2423 \\
-3.2794\end{array}$ & $\begin{array}{r}-0.6754 \\
0.3190 \\
1.0427 \\
-0.0597\end{array}$ \\
\hline $\begin{array}{l}\text { Weight } \\
{[\mathrm{kg}]}\end{array}$ & $\begin{array}{c}\text { osteopenia } \\
\text { osteoporosis } \\
\text { controls } \\
\text { total }\end{array}$ & $\begin{array}{l}0.026^{a} \\
0.001^{b}\end{array}$ & $\begin{array}{l}65.1721 \\
61.2088 \\
68.7273 \\
64.7204\end{array}$ & $\begin{array}{l}0.99502 \\
0.93755 \\
1.49288 \\
0.65801\end{array}$ & $\begin{array}{l}63.2022 \\
59.3462 \\
65.7458 \\
63.4251\end{array}$ & $\begin{array}{l}67.1420 \\
63.0714 \\
71.7088 \\
66.0157\end{array}$ \\
\hline $\begin{array}{l}\text { Height } \\
{[\mathrm{cm}]}\end{array}$ & $\begin{array}{c}\text { osteopenia } \\
\text { osteoporosis } \\
\text { controls } \\
\text { total }\end{array}$ & $\begin{array}{l}0.08^{a} \\
0.01^{b}\end{array}$ & $\begin{array}{c}162.6311 \\
160.2527 \\
163.0758 \\
161.9606\end{array}$ & $\begin{array}{l}0.45083 \\
0.52869 \\
0.73612 \\
0.32149\end{array}$ & $\begin{array}{l}161.7386 \\
159.2024 \\
161.6056 \\
161.3277\end{array}$ & $\begin{array}{c}163.5237 \\
161.3031 \\
164.5459 \\
162.5934\end{array}$ \\
\hline BMI & $\begin{array}{l}\text { osteopenia } \\
\text { osteoporosis } \\
\text { controls } \\
\text { total }\end{array}$ & $\begin{array}{l}0.04^{\mathrm{a}} \\
0.04^{\mathrm{b}}\end{array}$ & $\begin{array}{l}24.6445 \\
23.7879 \\
25.8802 \\
24.6574\end{array}$ & $\begin{array}{l}0.35747 \\
0.31784 \\
0.55665 \\
0.23299\end{array}$ & $\begin{array}{l}23.9368 \\
23.1564 \\
24.7685 \\
24.1988\end{array}$ & $\begin{array}{l}25.3522 \\
24.4193 \\
26.9919 \\
25.1161\end{array}$ \\
\hline $\begin{array}{l}\text { Age } \\
\text { [years] }\end{array}$ & $\begin{array}{c}\text { osteopenia } \\
\text { osteoporosis } \\
\text { controls } \\
\text { total }\end{array}$ & $\begin{array}{l}0.54^{\mathrm{a}} \\
0.014^{\mathrm{b}}\end{array}$ & $\begin{array}{l}53.2377 \\
56.0643 \\
53.3788 \\
54.4726\end{array}$ & $\begin{array}{r}0.73506 \\
0.74650 \\
1.01176 \\
0.47138\end{array}$ & $\begin{array}{l}51.7825 \\
54.5883 \\
51.3582 \\
53.5452\end{array}$ & $\begin{array}{l}54.6930 \\
57.5403 \\
55.3994 \\
55.3999\end{array}$ \\
\hline $\begin{array}{l}\text { Birth weight } \\
\text { [g] }\end{array}$ & $\begin{array}{c}\text { osteopenia } \\
\text { osteoporosis } \\
\text { controls } \\
\text { total }\end{array}$ & $\begin{array}{l}0.026^{a} \\
0.005^{b}\end{array}$ & $\begin{array}{l}3,226.7857 \\
3,141.2500 \\
3,628.9474 \\
3,326.3492\end{array}$ & $\begin{array}{r}77.68484 \\
134.07981 \\
110.29173 \\
63.20235\end{array}$ & $\begin{array}{l}3,067.3896 \\
2,855.4656 \\
3,397.2330 \\
3,200.0095\end{array}$ & $\begin{array}{l}3,386.1818 \\
3,427.0344 \\
3,860.6617 \\
3,452.6889\end{array}$ \\
\hline $\begin{array}{l}\text { Years } \\
\text { of reproduction }\end{array}$ & $\begin{array}{c}\text { osteopenia } \\
\text { osteoporosis } \\
\text { controls } \\
\text { total }\end{array}$ & $\begin{array}{l}0.724^{a} \\
0.528^{b}\end{array}$ & $\begin{array}{r}36.2000 \\
35.6154 \\
36.3750 \\
35.9936\end{array}$ & $\begin{array}{l}0.63682 \\
0.62160 \\
0.94586 \\
0.40144\end{array}$ & $\begin{array}{l}34.9257 \\
34.3736 \\
34.4459 \\
35.2007\end{array}$ & $\begin{array}{l}37.4743 \\
36.8572 \\
38.3041 \\
36.7866\end{array}$ \\
\hline $\begin{array}{l}\text { Age of first } \\
\text { menstruation }\end{array}$ & $\begin{array}{l}\text { osteopenia } \\
\text { osteoporosis } \\
\text { controls } \\
\text { total }\end{array}$ & $\begin{array}{l}0.636^{a} \\
0.754^{b}\end{array}$ & $\begin{array}{l}13.1167 \\
12.9385 \\
13.3750 \\
13.0955\end{array}$ & $\begin{array}{c}0.30908 \\
0.26843 \\
0.33224 \\
0.17517\end{array}$ & $\begin{array}{l}12.4982 \\
12.4022 \\
12.6974 \\
12.7495\end{array}$ & $\begin{array}{l}13.7351 \\
13.4747 \\
14.0526 \\
13.4416\end{array}$ \\
\hline $\begin{array}{l}\text { Age of last } \\
\text { menstruation }\end{array}$ & $\begin{array}{l}\text { osteopenia } \\
\text { osteoporosis } \\
\text { controls } \\
\text { total }\end{array}$ & $\begin{array}{l}0.069^{a} \\
0.058^{b}\end{array}$ & $\begin{array}{r}49.2099 \\
48.1585 \\
50.1707 \\
48.9804\end{array}$ & $\begin{array}{l}0.49588 \\
0.54804 \\
0.68512 \\
0.32876\end{array}$ & $\begin{array}{c}48.2230 \\
47.0681 \\
48.7860 \\
48.3322\end{array}$ & $\begin{array}{l}50.1967 \\
49.2490 \\
51.5554 \\
49.6286\end{array}$ \\
\hline $\begin{array}{l}\text { Number } \\
\text { of pregnancies }\end{array}$ & $\begin{array}{c}\text { osteopenia } \\
\text { osteoporosis } \\
\text { controls } \\
\text { total }\end{array}$ & $\begin{array}{l}0.869^{a} \\
0.902^{b}\end{array}$ & $\begin{array}{l}1.8852 \\
1.9560 \\
1.9394 \\
1.9211\end{array}$ & $\begin{array}{l}0.09821 \\
0.13525 \\
0.14940 \\
0.07075\end{array}$ & $\begin{array}{l}1.6908 \\
1.6873 \\
1.6410 \\
1.7819\end{array}$ & $\begin{array}{l}2.0797 \\
2.2247 \\
2.2378 \\
2.0604\end{array}$ \\
\hline $\begin{array}{l}\text { Years } \\
\text { after menopause }\end{array}$ & $\begin{array}{c}\text { osteopenia } \\
\text { osteoporosis } \\
\text { controls } \\
\text { total }\end{array}$ & $\begin{array}{l}0.854^{a} \\
0.001^{b}\end{array}$ & $\begin{array}{r}7.1833 \\
10.6308 \\
7.0313 \\
8.5796\end{array}$ & $\begin{array}{l}0.77769 \\
0.71305 \\
0.98832 \\
0.48209\end{array}$ & $\begin{array}{l}5.6272 \\
9.2063 \\
5.0156 \\
7.6273\end{array}$ & $\begin{array}{r}8.7395 \\
12.0553 \\
9.0469 \\
9.5319\end{array}$ \\
\hline $\begin{array}{l}\text { BMD } \\
\mathrm{L} 2-\mathrm{L} 4\left[\mathrm{~g} / \mathrm{cm}^{2}\right]\end{array}$ & $\begin{array}{l}\text { osteopenia } \\
\text { osteoporosis } \\
\text { controls } \\
\text { total }\end{array}$ & $\begin{array}{l}0.986^{\mathrm{a}} \\
0.944^{\mathrm{b}}\end{array}$ & $\begin{array}{l}0.9674 \\
0.9752 \\
0.9694 \\
0.9713\end{array}$ & $\begin{array}{l}0.02003 \\
0.01495 \\
0.02186 \\
0.01066\end{array}$ & $\begin{array}{l}0.9276 \\
0.9456 \\
0.9254 \\
0.9503\end{array}$ & $\begin{array}{l}1.0072 \\
1.0048 \\
1.0133 \\
0.9923\end{array}$ \\
\hline $\begin{array}{l}\text { BMD } \\
\text { L2-L4 YA [\%] }\end{array}$ & $\begin{array}{c}\text { osteopenia } \\
\text { osteoporosis } \\
\text { controls } \\
\text { total }\end{array}$ & $\begin{array}{l}0.965^{a} \\
0.982^{b}\end{array}$ & $\begin{array}{l}80.9022 \\
81.2783 \\
81.0204 \\
81.0938\end{array}$ & $\begin{array}{l}1.71939 \\
1.24077 \\
1.77293 \\
0.89537\end{array}$ & $\begin{array}{l}77.4868 \\
78.8203 \\
77.4557 \\
79.3305\end{array}$ & $\begin{array}{l}84.3175 \\
83.7362 \\
84.5851 \\
82.8570\end{array}$ \\
\hline $\begin{array}{l}\text { BMD L2-L4 } \\
\text { AM [\%] }\end{array}$ & $\begin{array}{c}\text { osteopenia } \\
\text { osteoporosis } \\
\text { controls } \\
\text { total }\end{array}$ & $\begin{array}{l}0.989^{a} \\
0.968^{b}\end{array}$ & $\begin{array}{l}89.1304 \\
89.5043 \\
89.7755 \\
89.4219\end{array}$ & $\begin{array}{l}1.82717 \\
1.23064 \\
1.93765 \\
0.93156\end{array}$ & $\begin{array}{l}85.5010 \\
87.0665 \\
85.8796 \\
87.5873\end{array}$ & $\begin{array}{l}92.7599 \\
91.9422 \\
93.6714 \\
91.2564\end{array}$ \\
\hline
\end{tabular}

$\mathrm{Cl}$ - confidence interval; ANOVA - analysis of variance; BMD - bone mineral density; BMI - body mass index; SEM - standard error of the mean; ${ }^{a}$ comparison between the groups with osteopenia and normal T-scores (one-way ANOVA); ${ }^{b}$ comparison between the groups with osteoporosis and normal T-scores (one-way ANOVA). 
In our study, we detected higher OR values in heterozygotes for rs4988321 SNP in women with both osteopenia $(\mathrm{OR}=1.47,95 \% \mathrm{CI}=0.57-3.63, \mathrm{p}=0.24)$ and osteoporosis $(\mathrm{OR}=1.33,95 \% \mathrm{CI}=0.67-2.75, \mathrm{p}=0.24)$. We were not able to determine the OR for the AA genotype in our groups due to its low incidence in the population. Elevated OR values for the A allele were found in women with osteopenia $(\mathrm{OR}=1.75,95 \% \mathrm{CI}=0.73-4.09, \mathrm{p}=0.11)$ and osteoporosis $(\mathrm{OR}=1.32,95 \% \mathrm{CI}=0.67-2.69, \mathrm{p}=0.25)$, which is consistent with the results of the study by van Meurs et al., who demonstrated the rs4988321 LRP5 polymorphism (Val667Met) to be associated with vertebral fractures and lowered BMD values, with the OR for fracture estimated at $1.26(95 \% \mathrm{CI}=1.08-1.47) .{ }^{14}$ The rs4988321(A) allele was associated with a reduced BMD of the lumbar vertebrae $\left(\mathrm{p}=3.3 \times 10^{-8}\right)$ and of the femoral neck $\left(\mathrm{p}=3.8 \times 10^{-5}\right)$. Similarly, Stathopoulou et al. observed an association between the rs4988330 polymorphism with the corrected $\mathrm{BMD}$ value, and the presence of the A allele was connected with significantly lower BMD as compared to the GG genotype, although a higher calcium intake (>680 mg/day) diminished the unfavorable influence of that polymorphism on BMD. ${ }^{19}$ In our study, all BMD values were higher only in the heterozygotes from the osteopenia group. Significant differences in the genotype distribution of the Val667Met (rs4988321) polymorphism were also reported for a population of Mexican women. ${ }^{20}$ Analyses of the LRP5 sequence polymorphism have visibly demonstrated ethnicity-related variations, as Sassi et al. found no correlation between the Val667Met genotype and the development of osteoporosis in Tunisian women. ${ }^{1}$ Previously, SNP Val667Met had been suggested to determine BMD in men as well. ${ }^{21}$ This might be explained by the fact that the polymorphic locus is located in the extracellular domain of the receptor, responsible for Dkk-1 binding, which - being the inhibitor of the pathway - might influence Wnt signaling activity. ${ }^{1}$ The genetic factor continues to play an important role in BMD determination and in the variability of its values between individuals. Based on the International HapMap Project and GWAS, candidate genes which might modify BMD values have been selected. Regardless, despite numerous candidate gene association studies, identification of genetic predispositions for osteoporosis continues. ${ }^{13}$ The literature offers countless examples that the Lrp5/ Wnt/ $\beta$-catenin pathway seems to be the main direction to establish effective therapies for diseases associated with lowered bone mass and increased risk for fractures. At present, although the influence of LRP5 and its homologues on BMD seems to be indisputable, the exact details of this association continue to be investigated. ${ }^{22,23}$

\section{References}

1. Sassi R, Sahli H, Souissi C, et al. Association of LRP5 genotypes with osteoporosis in Tunisian post-menopausal women. BMC Musculoskelet Disord. 2014;15:144.

2. Maupin KA, Droscha CJ, Williams BO. A comprehensive overview of skeletal phenotypes associated with alterations in Wnt/ $\beta$-catenin signaling in humans and mice. Bone Res. 2013;1(1):27-71.

3. Lara-Castillo N, Johnson ML. LRP receptor family member associated bone disease. Rev Endocr Metab Disord. 2015;16(2):141-148.

4. Costantini A, Mäkitie O. Value of rare low bone mass diseases for osteoporosis genetic. Bonekey Rep. 2016;5:773.

5. Krishnan V, Bryant HU, Macdougald OA. Regulation of bone mass by Wnt signaling. J Clin Invest. 2006;116(5):1202-1209.

6. Johnson ML. LRP5 and bone mass regulation: Where are we now? Bonekey Rep. 2012;1:1. doi: 10.1038/bonekey.2012

7. Kato M, Patel MS, Levasseur R, et al. Cbfa1-independent decrease in osteoblast proliferation, osteopenia, and persistent embryonic eye vascularization in mice deficient in Lrp5, a Wnt coreceptor. J Cell Biol. 2002;157(2):303-314.

8. Babij P, Zhao W, Small C, et al. High bone mass in mice expressing a mutant LRP5 gene. J Bone Miner Res. 2003;18(6):960-974.

9. Akhter MP, Wells DJ, Short SJ, et al. Bone biomechanical properties in LRP5 mutant mice. Bone. 2004;35(1):162-169.

10. Liedert A, Röntgen V, Schinke T, et al. Osteoblast-specific Krm2 overexpression and Lrp5 deficiency have different effects on fracture healing in mice. PloS One. 2014;9(7):e103250.

11. Burgers TA, Williams BO. Regulation of Wnt/ $\beta$-catenin signaling within and from osteocytes. Bone. 2013;54(2):244-249.

12. Wolski H, Drwęska-Matelska N, Seremak-Mrozikiewicz A, Lowicki Z, Czerny $\mathrm{B}$. The role of Wnt/ $\beta$-catenin pathway and LRP5 protein in metabolism of bone tissue and osteoporosis etiology [in Polish]. Ginekol Pol. 2015;86(4):311-314.

13. Zhang YP, Deng FY, Chen Y, et al. Replication study of candidate genes/loci associated with osteoporosis based on genome-wide screening. Osteoporos Int. 2010;21(5):785-795.

14. van Meurs JB, Trikalinos TA, Ralston SH, et al. GENOMOS Study. Largescale analysis of association between LRP5 and LRP6 variants and osteoporosis. JAMA. 2008;299(11):1277-1290.

15. Van Hul E, Gram J, Bollerslev J, et al. Localization of gene causing autosomal dominant osteoporosis type I to chromosome 11q12-13. J Bone Miner Res. 2002;17(6):1111-1117.

16. Agueda L, Bustamante M, Jurado S. A haplotype-based analysis of the LRP5 gene in relation to osteoporosis phenotypes in Spanish postmenopausal women. J Bone Miner Res. 2008;23(12):1954-1963.

17. Agueda L, Velázquez-Cruz R, Urreizti R, et al. Functional relevance of the BMD-associated polymorphism rs312009: Novel involvement of RUNX2 in LRP5 transcriptional regulation.J BoneMiner Res. 2011;26(5): 1133-1144.

18. Panach L, Mifsut D, Tarin JJ, Cano A, García-Pérez MÁ. Replication study of three functional polymorphisms associated with bone mineral density in a cohort of Spanish women. J Bone Miner Metab. 2014; 32(6):691-698.

19. Stathopoulou MG, Dedoussis GV, Trovas G, et al. Low-density lipoprotein receptor-related protein 5 polymorphisms are associated with bone mineral density in Greek postmenopausal women: An interaction with calcium intake. J Am Diet Assoc. 2010;110(7):1078-1083.

20. Falcon-Ramirez E, Casas-Avila L, Cerda-Flores RM, et al. Association of LRP5 haplotypes with osteoporosis in Mexican women. Mol Biol Rep. 2013;40(3):2705-2710.

21. Grundberg E, Lau EM, Lorentzon $M$, et al. Large-scale association study between two coding LRP5 gene polymorphisms and bone phenotypes and fractures in men. Osteoporos Int. 2008;19(6):829-837.

22. Li WF, Hou SX, Yu B, Li MM, Férec C, Chen JM. Genetics of osteoporosis: Accelerating pace in gene identification and validation. Hum Genet. 2010;127(3):249-285.

23. Kumar J, Swanberg M, McGuigan F, Callreus M, Gerdhem P, Akesson K. LRP4 association to bone properties and fracture and interaction with genes in the Wnt- and BMP signaling pathways. Bone. 2011;49(3):343-348. 